\title{
PENGARUH PROMOSI, ATMOSFER TOKO, DAN MOTIVASI BELANJA HEDONIS TERHADAP PEMBELIAN IMPULSIF KONSUMEN RITEL MODERN DI KOTA BATAM
}

\author{
Andi Erna Mulyana ${ }^{1)}$, Atika Pertiwi N.I ${ }^{2) 凶}$ \\ Jurusan Manajemen Bisnis, Politeknik Negeri Batam
}






\section{Pendahuluan}

Bisnis ritel merupakan kegiatan pemasaran untuk memenuhi kebutuhan perseorangan, keluarga, rumah tangga, dimana mereka merupakan konsumen akhir (Istiatin dan Sudarwati, 2014). Seiring dengan perkembangan bisnis ritel di Indonesia yang semakin pesat mendorong munculnya kelompok-kelompok bisnis yang semakin kompetitif dimana hal ini menuntut setiap perusahaan untuk semakin memperhatikan kebutuhan dan keinginan para konsumennya serta harus mampu mengenali dan memahami perilaku konsumen sehingga tercipta konsumen potensial. Salah satu cara yang dapat dipilih oleh perusahaan ritel untuk meningkatkan penjualan mereka yaitu dengan menciptakan dan meningkatkan perilaku pembelian tidak terencana (impulse buying) pada konsumen. Fitriana (2016) menyatakan bahwa perusahaan ritel memiliki beberapa pilihan dalam meningkatkan penjualan mereka salah satunya dengan menciptakan dan meningkatkan perilaku pembelian tidak terencana (impulse buying) pada konsumen.

Menurut In'am, dkk (2016) perilaku pembelian tiap individu dapat berbeda-beda. Sebelum melakukan pembelian suatu produk biasanya konsumen membuat perencanaan terlebih dahulu mengenai barang apa yang akan dibeli nanti. Perencanaan tersebut biasanya mencakup berbagai pertimbangan mengenai aspek dari produk yang ingin dibeli, harga, lokasi pembelian, dan lain sebagainya. Namun, sebagaimana telah dipaparkan sebelumnya bahwa setiap individu memiliki perilaku pembelian yang berbeda-beda, dimana ada kalanya pembelian yang dilakukan oleh individu timbul begitu saja saat melihat suatu produk sehingga proses pembelian terjadi tanpa ada perencanaan sebelumnya. Perilaku konsumen dalam melakukan jenis pembelian tersebut disebut sebagai impulse buying (pembelian impulsif). Impulse buying dapat disebabkan oleh beberapa faktor. Menurut Utami (2010) dalam jurnal Sari dan Suryani (2014) menyatakan bahwa salah satu penyebab terjadinya impulse buying ialah pengaruh stimulus dari tempat belanja tersebut.
Pemahaman akan perilaku impulse buying sepertinya juga diperoleh para produsen atau pemasar, terlihat dengan semakin banyak toko atau pusat perbelanjaan atau produsen dan pemasar lain yang memberikan banyak penawaran bagi (calon) konsumennya (Mulyono dan Fransisca, 2012), antara lain melalui program promosi. Oleh karena itu konsumen sering melakukan pembelian impulsif karena tertarik dengan promosi yang ditawarkan oleh perusahaan, seperti potongan harga, kupon undian dan hadiah (Indraswari dan Martono, 2016). Store atmosphere (suasana toko) juga berkaitan erat dengan impulse buying. Store atmosphere yang nyaman dapat meningkatkan kecenderungan konsumen untuk melihat-lihat barang yang ada di dalam toko untuk kemudian melakukan impulse buying. Fenomena perilaku impulse buying, juga didasari oleh faktor internal dari dalam diri konsumen tersebut. Faktor internal ini berhubungan dengan suasana hati dan kebiasaan konsumen dalam berbelanja. Salah satu motivasi yang didorong oleh emosi mencari kesenangan semata yaitu hedonic shopping motivation (motivasi belanja hedonis) dimana orang-orang yang memiliki motivasi belanja hedonis cenderung lebih mudah dalam melakukan impulse buying (Tjantoko dan Japarianto, 2015).

\section{Metode}

Objek penelitian pada penelitian ini adalah konsumen sebuah Department Store di Batam, dimana konsumen yang dijadikan sampel penelitian telah melakukan pembelian minimal tiga kali. Untuk mencukupi kebutuhan data, jumlah sampel pada penelitian ini adalah 100 orang konsumen yang dipilih secara acak. Pengumpulan data pada penelitian ini dilakukan dengan metode survey dengan menggunakan kuesioner (angket).

Metode penelitian yang digunakan adalah metode analisis deskriptif kuantatif, yaitu analisis yang datanya dapat dihitung untuk menghasilkan penafsiran kuantitatif untuk menbuktikan hipotesis-hipotesis berikut: 
H1: Terdapat pengaruh positif dan signifikan dari kegiatan promosi terhadap pembelian impulsif pelanggan sebuah Department Store di Batam.

H2: Terdapat pengaruh positif dan signifikan dari atmosfer toko terhadap pembelian impulsif pelanggan sebuah Department Store di Batam.

H3: Terdapat pengaruh positif dan signifikan motivasi belanja hedonis terhadap pembelian impulsif pelanggan sebuah Department Store di Batam.

H4: Terdapat pengaruh positif dan signifikan dari kegiatan promosi, atmosfer toko, dan motivasi belanja hedonis secara simultan terhadap pembelian impulsif pelanggan sebuah Department Store di Batam.

Data yang diperoleh diolah terlebih dahulu dengan melakukan uji validitas dan realibilitas. Data-data yang dinyatakan valid dan siap untuk digunakan, diuji lebih lanjut dengan menggunakan uji $\mathrm{T}$ dan Uji F. Uji T digunakan untuk mengukur sejauh mana pengaruh variable bebas yaitu promosi, atmosfer toko, dan motivasi belanja hedonis terhadap pembelian impulsif yang merupakan variable terikat pada penelitian ini. Kemudian uji $\mathrm{F}$ digunakan untuk melihat bagaimana pengaruh semua variable bebas secara bersama-sama terhadap variable terikat. Hasil pengujian inilah yang kemudian dianalisis untuk menarik sebuah kesimpulan pada penelitian ini.

\section{Hasil dan Pembahasan}

H1: Terdapat pengaruh positif dan signifikan dari kegiatan promosi terhadap pembelian impulsif pelanggan sebuah Department Store di Batam.

Hasil uji t diperoleh thitung sebesar 4,794 dengan signifikansi 0,000 (sig < 0,05). Hasil ini menunjukkan angka signifikansi lebih kecil dari $0,05(0,000<0,05)$ dan thitung sebesar 4,794> ttabel 1,988, sehingga dapat disimpulkan bahwa terdapat pengaruh positif dan signifikan antara variabel promosi terhadap pembelian impulsif. Hal ini sejalan dengan beberapa penelitian sebelumnya seperti penelitian yang dilakukan oleh Indraswari dan Martono (2016), Amanah dan Pelawi (2015) serta Wauran dan Poluan (2016) yang menyatakan bahwa promosi berpengaruh positif dan signifikan terhadap pembelian impulsif. Promosi merupakan alat komunikasi untuk menghubungkan keinginan pihak peritel dengan konsumen untuk memberitahu, membujuk, dan mengingatkan konsumen agar mau membeli produk yang dijual (Utami, 2010). Penawaran melalui kegiatan promosi ini akan memicu keinginan pelanggan untuk melakukan pembelian terhadap produkproduk tanpa terencana.

Tabel 1. Hasil Uji t Promotion



H2: Terdapat pengaruh positif dan signifikan dari atmosfer toko terhadap pembelian impulsif pelanggan sebuah Department Store di Batam.

Hasil uji $\mathrm{t}$ diperoleh thitung sebesar 3,625 dengan signifikansi sebesar 0,000 (sig < 0,05). Hasil ini menunjukkan angka signifikansi lebih kecil dari $0,05(0,000<0,05)$ dan nilai thitung $>$ ttabel $(3,625>1,988)$ sehingga dapat

disimpulkan bahwa terdapat pengaruh positif dan signifikan antara variabel atmosfer toko terhadap pembelian impulsif. Hal ini sejalan dengan beberapa penelitian sebelumnya yang dilakukan oleh Wijaya (2014) serta Setiawardani (2019) yang menjelaskan bahwa atmosfer toko berpengaruh positif dan signifikan terhadap pembelian impulsif. Atmosfer toko atau suasana toko merupakan suasana terencana yang sesuai 
dengan target konsumen dan yang dapat menarik konsumen untuk membeli. Penciptaan suasana dalam toko dengan rancangan lingkungan melalui komunikasi visual, pencahayaan, warna, musik, dan wangi-wangian ditunjukan untuk meransang respon emosional dan perseptual pelanggan dan untuk memengaruhi pelanggan dalam membeli barang (Utami, 2010). Hal ini terbukti sangat berpengaruh dalam membangkitkan minat konsumen untuk berbelanja secara tak terencana.

Tabel 2. Hasil Uji t Store Atmosphere

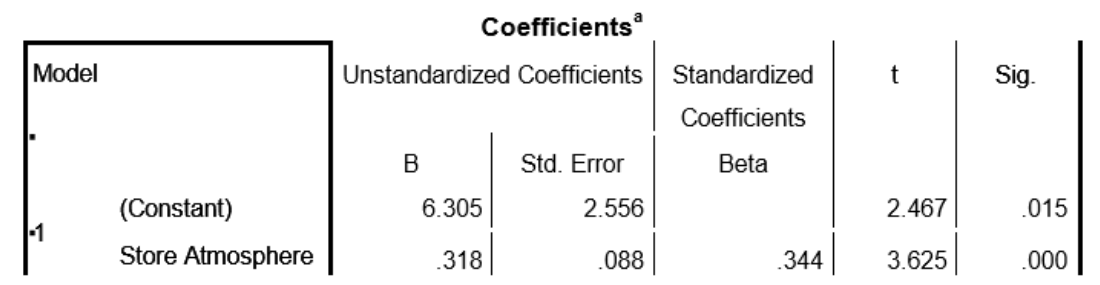

a. Dependent Variable: Impulse Buying

H3: Terdapat pengaruh positif dan signifikan motivasi belanja hedonis terhadap pembelian impulsif pelanggan sebuah Department Store di Batam.

Hasil uji t diperoleh thitung sebesar 4,963 dengan signifikansi sebesar 0,000 ( $\operatorname{sig}<0,05$ ). Hasil ini menunjukkan angka signifikansi lebih kecil dari $0,05(0,000<0,05)$ dan nilai thitung > ttabel $(4,963>1,988)$ sehingga dapat disimpulkan bahwa terdapat pengaruh positif dan signifikan antara variabel motivasi belanja hedonis terhadap pembelian impulsive. Hal ini ini sejalan dengan penelitian-penelitian sebelumnya seperti yang dilakukan oleh Tabel 3. Hasil Uji t Hedonic Shopping Motivation
Hursepuny dan Oktafani (2018) serta Amanah dan Pelawi (2015) yang menjelaskan bahwa motivasi belanja hedonis berpengaruh positif dan signifikan terhadap pembelian impulsif. Menurut Utami (2010) motivasi konsumen untuk berbelanja dapat dibagi menjadi dua yaitu Utilitarian Shopping Motivation dan Hedonic Shopping Motivation (Motivasi Belanja Hedonis). Keputusan pembelian lebih dipengaruhi oleh hedonic motivation dibanding dengan utilitarian motivation. Manfaat hedonis mencakup respons emosional, kesenangan pancaindra, mimpi, dan pertimbangan estetis seringkali membuat konsumen seketika merasa tertarik terhadap suatu produk yang ditawarkan.



a. Dependent Variable: Impulse Buying

H4: Terdapat pengaruh positif dan signifikan dari kegiatan promosi, atmosfer toko, dan motivasi belanja hedonis secara simultan terhadap pembelian impulsif pelanggan sebuah Department Store di Batam.
Hasil uji $\mathrm{F}$ yang menunjukkan fhitung $>$ ftabel dengan fhitung 10,759 > ftabel 2,70 dengan nilai sig. 0,000 yang lebih kecil dari derajat kepercayaan yang digunakan yaitu $\alpha=0,05$ $(0,000<0,05)$ sehingga dapat disimpulkan bahwa variabel promosi, atmosfer toko, dan 
motivasi belanja hedonis berpengaruh positif dan signifikan terhadap pembelian impulsif secara bersama-sama (simultan)

Tabel 4. Hasil Uji F (Simultan)

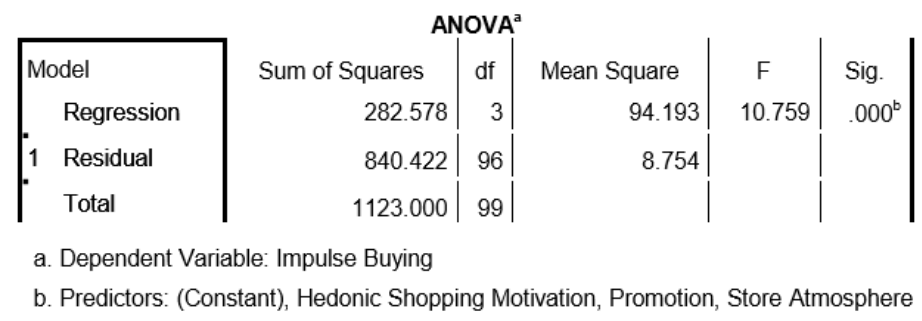

\section{Kesimpulan}

Berdasarkan hasil penelitian dan pembahasan pada penelitian ini dapat disimpulkan bahwa:

1) Kegiatan promosi berpengaruh positif dan signifikan terhadap pembelian impulsif

2) Atmosfer toko berpengaruh positif dan signifikan terhadap pembelian impulsif

3) Motivasi belanja hedonis berpengaruh positif dan signifikan terhadap pembelian impulsif

4) Promosi, atmosfer toko, dan motivasi belanja hedonis secara simultan berpengaruh positif dan signifikan terhadap pembelian impulsif

\section{Daftar Pustaka}

Amanah, Dita dan Stephany P. Pelawi. 2015. Pengaruh Promosi Penjualan (Sales Promotion) dan Belanja Hedonis (Hedonic Shopping) Terhadap Impulsive Buying Produk Matahari Plaza Medan Fair. Vol.III No.02 Jurnal Quanomic.

Fitriana, A. (2016). Analisis Pengaruh Display Interior Terhadap Perilaku Pembelian Impulsif Konsumen Indomaret Pontianak. Vol. 1, No.2, 90-102 Journal of Applied Intelligent System.

Hursepuny, Crusyta Valencia dan Farah Oktafani. 2018. Pengaruh Hedonic Shopping Motivation dan Shopping Lifestyle Terhadap Impulse Buying pada Konsumen Shopee_Id. Vol.5 No.1 e-Proceedings of Management.

Indraswari, G. R., \& S. Martono. (2016). Pengaruh Promosi Terhadap Impulse Buying Dengan Gender Sebagai Variabel Dummy. Vol.5 No.2 Management Analysis Journal.

In'am F. M, dkk. (2016). Analisis Faktor-Faktor Yang Berpengaruh Terhadap Pembelian Impulsif
(Studi pada Pengunjung yang Melakukan Pembelian Impulsif di Distro 3Second Cabang Mall Olympic Garden Malang). Vol. 36 No. 1 Juli 2016 Jurnal Administrasi Bisnis (JAB).

Istiatin, \& Sudarwarti. (2015). Analisis Strategi Pemasaran Bisnis Retail di Lottemarket Surakarta. Vol.12 Jurnal Paradigma.

Mulyono, \& Fransisca. (2012). Faktor Demografis dalam Pembelian Impulsif. Jurnal Administrasi Bisnis, 88-105.

Sari, D. A., \& Suryani, A. (2014). Pengaruh Merchandising, Promosi Dan Atmosfer Toko Terhadap Impulse Buying. E-Jurnal Manajemen Universitas Udayana.

Setiawardani, M. 2019. Pengaruh Suasana Toko Terhadap Pembelian Impulsif (Kajian Empiris Pada Gerai Miniso di Kota Bandung). Vol.5 No.1 Jurnal Riset Bisnis dan Investasi.

Tjantoko, L. E., \& Japarianto, E. (2015). Analisa Pengaruh Promosi Dan Hedonic Motivation Terhadap Impulse Buying di Ron's Laboratory Galaxy Mall Surabaya. Vol, 3 No. 1, 1-7 Jurnal Manajemen Pemasaran Petra.

Utami, C. W. (2010). Manajemen Ritel (Strategi dan Implementasi Operasional Bisnis Ritel Modern di Indonesia). Jakarta: Salemba Empat.

Wauran, Pricylia dan Jane Grace Poluan. 2016. Pengaruh Promosi Penjualan Dan Servicescape Terhadap Impulse Buying Dengan Shopping Emotion Sebagai Variabel Intervening. Vol.16 No.4 Jurnal Berkala Ilmiah Efisiensi.

Wijawa, Chandra Agung. 2014. Pengaruh Atmosfer Toko Terhadap Pembelian Impulsif (Survei Pada Konsumen Yang Melakukan Pembelian Impulsif Pada Giant Hypermarket Mall Olympic Garden Kota Malang). Vol.17 No.2 Jurnal Administrasi Bisnis. 